\title{
Crítica de Filme: Segunda-Feira ao Sol (Los Lunes al Sol)*
}

\author{
Ignez Gurgel $^{* *}$
}

\section{Ficha Técnica}

Direção: Fernando León de Aranoa

Ano: 2002

País: Espanha

Duração: 113 min.

Elenco: Javier Bardem (Santa), Luis Tosar (José), José Ángel Egido (Lino), Nieve de Medina (Ana), Enrique Villén (Reina), Celso Bugallo (Amador), Joaquín Climent (Rico), Aida Folch (Nata), Serge Riaboukine (Serguei), Laura Domínguez (Ángela), Pepo Oliva (Samuel), Fernando Tejero (Lázaro) Roteiro: Fernando León de Aranoa e Ignacio del Moral

Música: Lucio Godoy

Produção: Elías Querejeta

Fotografia: Alfredo Fernández Méndez

Montagem: Nacho Ruiz Capillas

Direção Artística : Julio Esteban

Vestuário: Maiki Marín

\footnotetext{
* Filme do Diretor Espanhol Fernando León de Aranoa - Nasceu na cidade de Madrid, Espanha, em 1968. Iniciou sua carreira como desenhista e ilustrador, porém só ficou conhecido pelos seus roteiros para televisão e depois para o cinema, isto lhe deu respaldo para filmar seus próprios filmes. "Los Lunes al Sol", foi filmado em 2002; ganhou cinco prêmios no Goya, em diversas categorias, ganhou três kikitos de ouro, no Festival de Gramado - melhor diretor, melhor filme e melhor ator - Javier Bardem, no Festival de San Sebastían, ganhou o prêmio de melhor diretor.

** Doutoranda do Programa de Pós-Graduação em Integração da América Latina - PROLAM/USP. Mestre em Educação pela Universidade Estadual de Campinas - UNICAMP.
} 
"Todas mis peliculas son una huida de la realidad. Los personajes sienten la necesidad de inventarse otra vida a su medida y vivirla en su imaginación"

O diretor Fernando León Aranoa trabalha com algumas imagens documentais, mesmo sendo um filme ficcional. Imagens estas que nos remetem às manifestaçóes entre trabalhadores versus polícia, quando fecharam os estaleiros navais.

O filme é ambientado em uma cidade portuária ao norte da Espanha, o porto fica na regiáo da Galícia. O estaleiro naval em que trabalhavam foi comprado por investidores coreanos, que construiriam no local um hotel turístico de alto luxo. $\mathrm{O}$ diretor segue algumas linhas do neo-realismo italiano, a temática social, humanista, a ruína física e psicológica das personagens, e também dos locais, as tomadas externas. Utiliza o plano geral em muitas cenas, close (proximidade do objeto ou rosto ator), o campo (tudo o que está presente na imagem) e o contra-campo (uma tomada feita com a câmera orientada em direção oposta à posição da tomada anterior), além de compor muitas cenas com luz e sombra excessivas.

Sua câmera segue com precisão um caminho circular, do vazio, dos conflitos, das errâncias, num tempo em as personagens flutuam sem perspectiva, no qual silêncios e açóes, palavras e imagens dialogam. Exoperários e amigos se reúnem diariamente no bar Naval, que pertence a um deles, Rico (ex-operário), lá bebem e narram seus dramas pessoais. Desempregados há bastante tempo, buscam um lugar ao sol. É um filme que trata da situação social do desemprego, da transformação de trabalhadores em pessoas sem identidade social, pois suas habilidades como trabalhadores de nada serve depois que o estaleiro foi extinto. São forçados pelas circunstâncias a procurar trabalho na informalidade, com mais de quarenta anos, nenhum deles consegue emprego no mercado formal de trabalho. São filhos de mais de uma década de estagnação.

As personagens principais do filme são nove: Santa (interpretado por Javier Bardem, que compóe esta personagem com maestria), homem solitário, sonhador, sociável, transgressor, ex-líder sindical, ele conduz o filme. Lino tem uma família estruturada. Sua mulher não trabalha, faz serviços domésticos,

${ }^{1}$ Frase do diretor Fernando León de Aranoa sobre seus filmes. 
e a sua maior preocupação é a falta de emprego. Tem um filho adolescente, também desempregado, vive de pequenos serviços ocasionais, pai e filho se encontram numa situação similar: a do desemprego. Lino sustenta a família com o dinheiro do seguro-desemprego. Ainda vai a entrevistas de trabalho, acreditando ser inserido novamente no trabalho formal.

Em Cacciamali (2002):

O ambiente econômico contemporâneo, por outro lado, configura um tipo de mercado de trabalho no qual um dos traços marcantes é o aumento da insegurança laboral, subjetiva e objetiva. Essa insegurança deriva tanto do menor ritmo de crescimento econômico e conseqüente menor criação de oportunidades de emprego, como das mudanças institucionais implementadas para atender às necessidades da flexibilidade laboral, e aquelas originárias das mudanças tecnológicas e da reestruturação produtiva, como, por exemplo, aumento do desemprego, mudança no conteúdo das ocupaçôes e maior necessidade de manter a empregabilidade, entre outras.

José é outro ex-metalúrgico naval. É casado com Ana, operária, assalariada da indústria de conservas de atum, ela trabalha à noite em condiçóes subhumanas. Ana sofre com dores nas pernas, pois é obrigada a ficar quase oito horas em pé na linha de produção. Ana é que sustenta José e este sentese excluído - do mercado de trabalho e do amor da mulher. José é um personagem inerte, apenas divaga, ao lado de Santa e dos companheiros de bar. Em Pochmann (1999, p. 20):

Embora os excluídos sejam parte integrante da sociedade em cada país (estado de privaçáo), estes tendem a se encontrar desprovidos das condiçôes materiais que os possibilitem usufruir de benefícios sócioeconômicos (emprego, rendimento) ou de condiçôes institucionais (direitos e deveres) possíveis nos marcos do desenvolvimento capitalista.

Amador é um personagem interessante. É a própria expressão da crise proletária. Ele expóe a situação-limite dos parceiros desempregados do Bar Naval. Amador é o vazio, o nada, representa a perda de sentido da realidade. 
Em seus raros diálogos, divaga através de parábolas, sobre a essência do mundo burguês. Esconde dos companheiros que sua mulher o abandonou. O suicídio de Amador, traduz o ponto final de uma vida sem sentido. Serguei é um imigrante russo, também desempregado, não consegue se relacionar bem com os companheiros, não conhece bem o país em que mora e nem mostra nenhum interesse em voltar para sua terra natal. Rico é do dono do bar onde todos se encontram, deixou o trabalho no estaleiro para ser negociante, passa pelo processo de readaptação à nova realidade do trabalho. Reina é vigilante noturno de um edifício em construção, o qual fica perto do estádio de futebol local, trabalha num sub-emprego, é explorado, porém não vê perspectivas de mudança, o fato de trabalhar o distancia dos companheiros desempregados. Ana é lutadora, assimila as mudanças mais facilmente e tenta ajudar o marido. É a força de trabalho feminina utilizada como mão de obra barata. Nata observa todos e representa uma nova geração que não é marcada pelo paradigma do trabalho de fábrica ou industrial.

Os desempregados perdem a noção de temporalidade, são pouco pragmáticos e efetivos; por isso homens e mulheres desempregados são indivíduos repletos de negação. A personagem Santa sempre interroga/ pergunta: "que dia é hoje?" E a resposta é sempre a mesma, todo dia é segunda-feira ao sol. 


\section{Referências Bibliográficas}

CACCIAMALI, Maria Cristina. Princípios e direitos fundamentais no trabalho e na América Latina. São Paulo em Perspectiva, São Paulo, v. 16, n. 2, 2002.

POCHMANN, Márcio. O trabalho sob fogo cruzado. São Paulo: Editora Contexto, 1999.

\section{Filmografia}

Segunda-Feira ao Sol (Los Lunes al Sol). Direção: Fernando León de Aranoa, 2002. 